\title{
Early larval development in the laboratory of Alpheus estuariensis (Crustacea: Caridea) from the Amazon Region
}

\author{
Marcus A. B. Pires; Fernando A. Abrunhosa \& Cristiana R. Maciel
}

Campus Universitário de Bragança, Universidade Federal do Pará. Alameda Leandro Ribeiro, Aldeia, 68600-000 Bragança, Pará, Brasil.E-mail: marcuspirex@gmail.com; faraujo@ufpa.br; macielufpa@gmail.com

\begin{abstract}
Here we describe and illustrate in detail four early zoeal stages of Alpheus estuariensis Christoffersen, 1984 from larvae reared in the laboratory. Two ovigerous females were collected in the tidal creek of the Bragança estuary, state of Pará, northeastern Brazil. After hatching, the larvae were placed in small containers (with 10 larvae in each). Females were deposited in the Museu Paraense Emilio Goeldi (MPEG 0803) and the larvae of each larval stage in the Zoological Museum of São Paulo University (MUSP18452). Ten larvae and exuviae were dissected with fine needles under an ocular microscope. Morphological comparisons with previous studies on larval development of the Alpheus species are briefly discussed.
\end{abstract}

KEY WORDS. Alpheidae; larval development; morphology.

RESUMO. Os estágios iniciais de Alpheus estuariensis (Crustacea: Caridea) da Região Amazônica, cultivado em laboratório. O presente estudo descreve e ilustra em detalhes os quatro primeiros estágios de Alpheus estuariensis Christoffersen, 1984 a partir de larvas cultivadas em laboratório. Duas fêmeas ovígeras foram coletadas no canal de maré do estuário de Bragança, estado do Pará, nordeste do Brasil. Após a eclosão, as larvas foram colocadas em pequenos recipientes (com 10 larvas em cada). As fêmeas foram depositadas no Museu Paraense Emilio Goeldi (MPEG 0803) e as larvas de cada estágio larval no Museu zoológico da Universidade de São Paulo (MUSP18452). Foram dissecadas 10 larvas e exúvias com finas agulhas sob um microscópio ocular. Comparações morfológicas com outros estudos reportados sobre o desenvolvimento larval de espécies de Alpheus são brevemente discutidas.

PALAVRAS-CHAVE. Alpheidae; desenvolvimento larval; morfologia.

Twenty-three species of snapping shrimp in Alpheus Fabricius, 1798 are known from Brazilian waters (CHRISTOFFERSEN 1998). Among these species, four are restricted to estuaries: Alpheus estuariensis Christoffersen, 1984, A. chacei Carvalho, 1979, A. pontederiae Rochebrune, 1883 and A. heterochaelis Say, 1818 (CHRISTOFFERSEN 1984).

Alpheus estuariensis is often associated with hard structures, such as stones, oysters or mangrove roots, or with extremely soft mud, characteristic of water run-off in mangroves (Christoffersen 1984). This species has been recorded from Ceará to Paraná (Christoffersen 1984, 1998). While Alpheidae larvae often comprise a significant portion of inshore meroplankton, larval descriptions within this family are poorly known (KNowlton 1973, YAng 2003, YAng et al. 2003, Bartilotti et al. 2005). In Brazil, among those species recorded by CHRISTOFFersen (1998), Guterres et al. (2005) and Mossolin et al. (2006) some or all larval stages were described for $A$. armillatus $\mathrm{H}$. MilneEdwards, 1837 (as A. heterochaelis) by BRоOкS \& HerRICK (1892), A. normanni Kingsley, 1878 by Вroокs \& HerRick (1892), A. macrocheles (Hailstone, 1835) by Lebour (1932) and A. heterochaelis by KNOWLton (1973) and Gross \& KNowlton (1999), as described by YANG \& KIM $(1996,1999)$. Alpheus heterochaelis was unique in that complete development of an Alpheus in laboratory was described (YANG \& KIM 1996).

Here we describe and illustrate in detail the early zoeal stages of A. estuariensis. We also compare these stages with those of other congeneric species.

\section{MATERIAL AND METHODS}

Two ovigerous females of $A$. estuariensis (carapace length 10.45 and $10.61 \mathrm{~mm}$ ) were caught with a dip net in the Furo Grande tidal creek in the Bragança estuary, state of Pará, northeastern Brazil ( $\left.0^{\circ} 50^{\prime} 25.3^{\prime \prime} \mathrm{S}, 46^{\circ} 38^{\prime} 21.7^{\prime \prime} \mathrm{W}\right)$. In the laboratory, the females were kept in separate 11 containers in filtered $(5 \mu)$ marine water $(35 \%)$, with constant aeration, until the eggs hatched. After hatching, the larvae were placed in small containers (polyethylene, $150 \mathrm{ml}, 10$ larvae in each). Females were deposited in the Museu Paraense Emilio Goeldi (MPEG 0803) and the larvae of each larval stage in the Museu de Zoologia, Universidade de São Paulo (MUSP18452).

Temperature of the culture was maintained at $28^{\circ} \mathrm{C}( \pm 1.5)$ and $\mathrm{pH}$ was kept at $8.1( \pm 1.0)$. Every two days, the larvae were

Revista Brasileira de Zoologia 25 (2): 199-205, June, 2008 

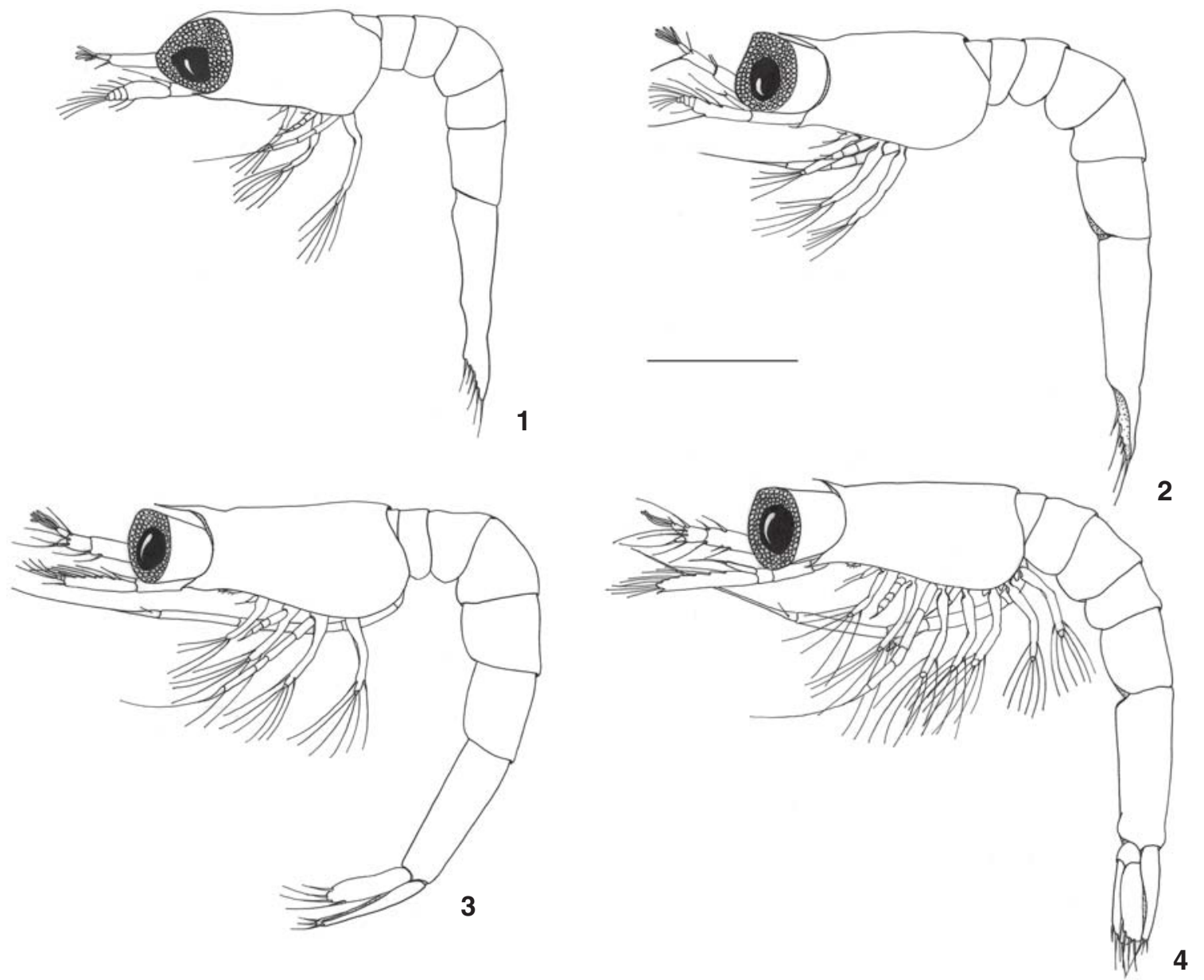

Figures 1- 4. Alpheus estuariensis, zoeal stages in lateral view: (1) stage I; (2) stage II; (3) stage III; (4) stage IV. Scale bar: 0.6 mm.

transferred to new containers. Microalgae Thalassiosira sp. was provided daily at a density of $4 \times 10^{4} / \mathrm{ml}$. Larvae were fed with rotifers (Brachionus sp., 200 ind.ml) and Artemia nauplii (8-10 ind.ml).

At least 10 larvae and exuviae from each larval stage were preserved in alcohol $70 \%$ and subsequently immersed in glycerol+ethanol 70\% solution (1:1). Samples were dissected using fine needles under an ocular microscope. Carapace length was measured from the tip of the rostrum to the posterior margin of the telson. Carapace length is the distance between the orbital margin to the posterior portion of the carapace.

The terminology used here follows KNOwLTON (1973), YANG \& KIM $(1996,1998,1999,2002)$ and YANG et al. (2003).

\section{RESULTS}

Larvae passed through four zoeal stages in four days (at a rate of one stage per day), when they reached zoea IV. All larvae survived to the moult of stage zoea IV, but died on the $5^{\text {th }}$ day of culture. We describe the first zoeal stage in detail, and subsequent stages are described as they differ from zoel I.

\section{Zoea I}

Carapace length: $2.81 \mathrm{~mm}(2.7-3.0 \mathrm{~mm})$. Carapace (Fig. 1): Eyes sessile; rostrum absent; pterygostomian spines present. Antennule (Fig. 5): unsegmented, with long inner plumose flagellum; outer flagellum with four aesthetascs and 1 short plumose seta. Antenna (Fig. 6): peduncle unsegmented; endopod with 1 long plumose seta and 1 small spine on apex; exopod 4segmented distally with 9+2 plumose setae. Maxillule (Fig. 7): endopod unsegmented with 1 small terminal seta; basal endite with two stout spines; coxal endite with three distal setae. Maxilla (Fig. 8): scaphognathite with five plumose setae; basal and coxal endites similar, each endite with proximal and distal lobes fused bearing 2 and two plumose setae, respectively. Maxilliped 1 (Fig. 9): protopod lacking setae; endopod short, unsegmented, with a long terminal spine; exopod longer than endopod with $2+2$ natatory setae. Maxilliped 2 (Fig. 10):

Revista Brasileira de Zoologia 25 (2): 199-205, June, 2008 

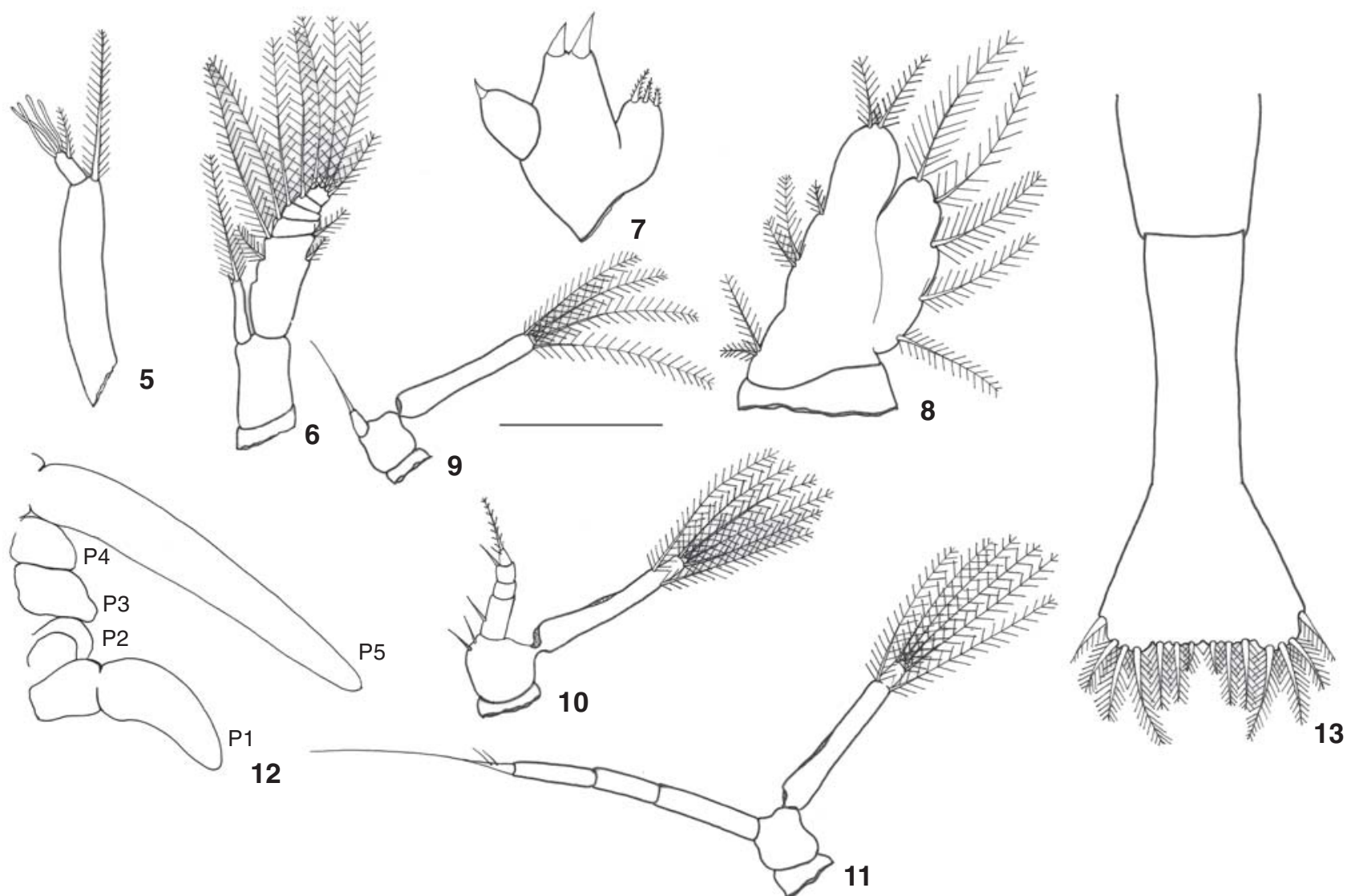

Figures 5-13. Alpheus estuariensis, zoea I appendages: (5) antennule; (6) antenna; (7) maxillule; (8) maxilla; (9) first maxilliped; (10) second maxilliped; (11) third maxilliped; (12) pereiopods P1-P5; (13) telson. Scale bar: 5-6, 9-11 and $13=0.3 \mathrm{~mm}, 7-8=0.075 \mathrm{~mm}, 12=0.15 \mathrm{~mm}$.

protopod with two simple setae; endopod 4-segmented with setal formula 1-0-1-2; exopod with 2+2+2 natatory setae. Maxilliped 3 (Fig. 11): protopod lacking setae; endopod slightly longer than exopod and 4-segmented, with setal formula $0+0+0+3$; exopod with $2+2+2$ natatory setae. Pereiopod 1-5 (Fig. 12): Pereipods 1-5 biramous, undeveloped, lacking setae. Abdomen (Fig. 1): 6-segmented, $6^{\text {th }}$ segment fused with telson. Telson (Fig. 13): triangular, posterior margin almost straight with rounded edges bearing $14(7+7)$ plumose setae.

\section{Zoea II}

Carapace length: $3.18 \mathrm{~mm}$ (3.15-3.20 mm). Carapace (Fig. 2): eyes stalked; rostrum short, untoothed. Antennule (Fig. 14): peduncle 2-segmented, proximal segment with two distal setae, distal segment with one plumose seta; outer flagellum with four aesthetascs. Antenna (Fig. 15): basal segment with 1 spine; exopod with 9+2 plumose setae; endopod with one long plumose seta and one spine on the apex. Maxillule (Fig. 16): endopod with one plumose seta on the apex; coxal endite with two distal plumose setae. Maxilla (Fig. 17): scaphognathite 6 with plumose setae; basal and coxal endites with proximal and distal lobes fused, coxal endite with four setae, basal endite with three setae. Maxilliped 1 (Fig. 18): protopod with four simple setae; endopod unsegmented with setal formula $1+2$ setae. Maxilliped 2 and 3 (Figs 19 and 20): similar to the previous stage. Pereiopod 1-5 (Fig. 21): pereiopods 1-similar to previous stage with exopods of pereiopods 1, 2 and 5 with undeveloped natatory setae. Abdomen (Fig. 2): unchanged. Telson (Fig. 22): as previous stage with addition of two small nonplumose median spines.

\section{Zoea III}

Carapace length: $3.42 \mathrm{~mm}$ (3.35-3.5 mm). Carapace (Fig. 3): unchanged. Antennule (Fig. 23): peduncle 2-segmented, proximal and distal segments with two and three long plumose setae, respectively. Antenna (Fig. 24): exopod with 11+1 plumose setae. Maxillule (Fig. 25): coxal endite with four setae. Maxilla (Fig. 26): scaphognathite with five plumose setae. Maxilliped 1 (Fig. 27): protopod with five simple setae. Maxilliped II (Fig. 28): unchanged. Maxilliped III (Fig. 29): unchanged. Pereiopod 1 (Fig. 30): well developed; endopod 4-segmented, distal segment ending with a spine; exopod developed with 22-2 natatory setae. Pereiopod 2 (Fig. 31): endopod undeveloped; exopod developed with 2-2-2 natatory setae. Pereiopods

Revista Brasileira de Zoologia 25 (2): 199-205, June, 2008 


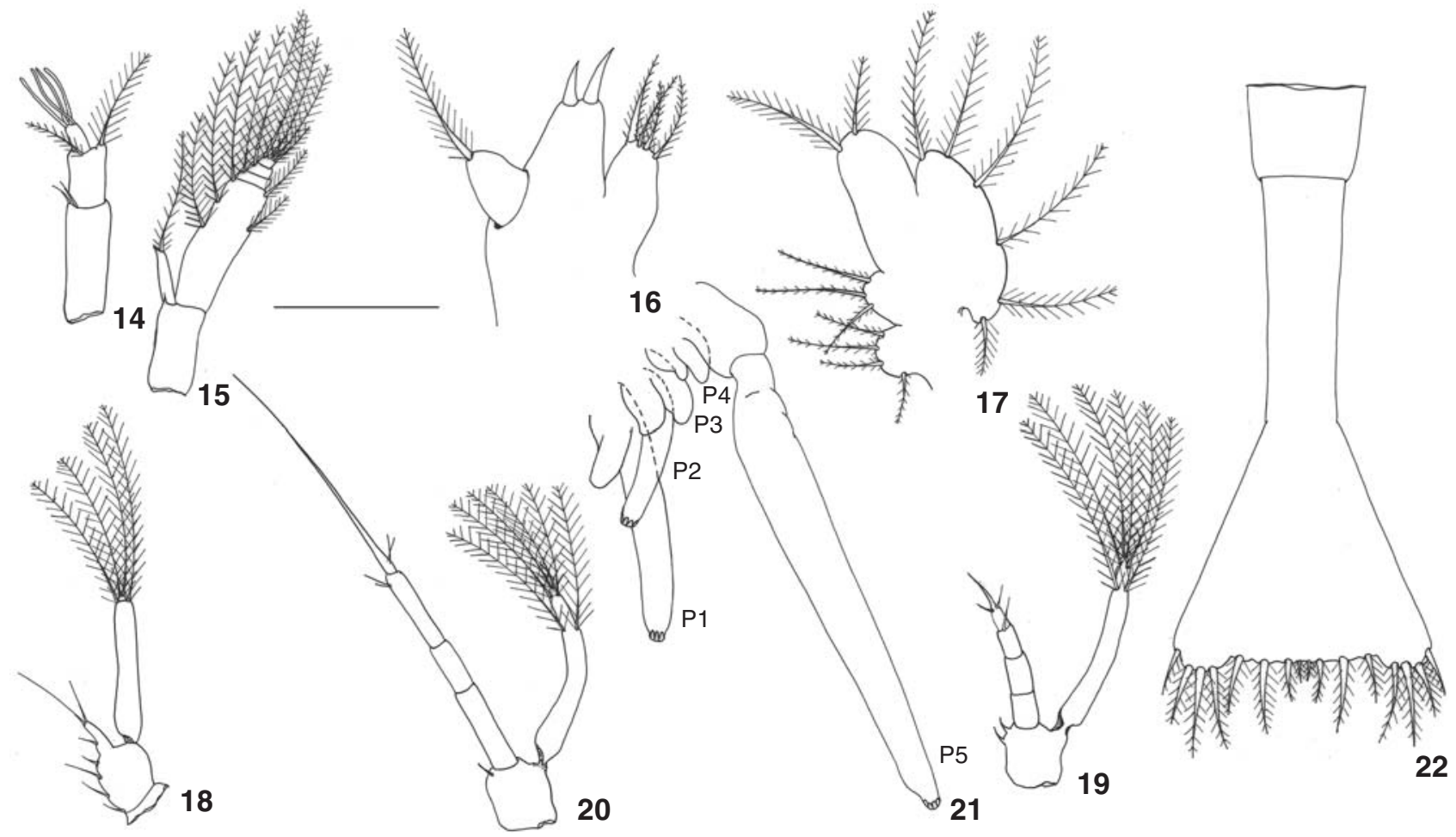

Figures 14-22. Alpheus estuariensis, zoea II appendages: (14) antennule; (15) antenna; (16) maxillule; (17) maxilla; (18) first maxilliped; (19) second maxilliped; (20) third maxilliped; (21) pereiopods P1-P5; (22) telson. Scale bar: 14-15, 18-20 and $22=0.3 \mathrm{~mm}, 16-17=$ $0.750 \mathrm{~mm}, 21=0.15 \mathrm{~mm}$.

3-4 (Figs 32 and 33). bud, biramous. Pereiopod 5 (Fig. 34): endopod well-developed, 4-segmented with setal formula 0-01-1 ending with a elongate spine. Abdomen (Fig. 3): $6^{\text {th }}$ segment articulated with telson. Telson (Fig. 35): margin posterior with seven pair of setae, an additional pair of small spines on lateral margin; exopod with 6 plumose setae.

\section{Zoea IV}

Carapace length: $3.83 \mathrm{~mm}(3.75-4.0 \mathrm{~mm})$. Carapace (Fig. 4): unchanged. Antennule (Fig. 36): peduncle 2-segmented, proximal and distal segments with five and four long plumose setae, respectively; outer flagellum with two aesthetascs and one small seta. Antenna (Fig. 37): endopod with two setae on apex; exopod with $11+1$ plumose setae and two small spines on outer margin. Maxillule (Fig. 38): unchanged, from previous stage. Maxilla (Fig. 39): scaphognathite with seven plumose setae; coxal endite with three setae, basal endite three and four setae on the proximal and distal lobes, respectively. Maxilliped 1 (Fig. 40): endopod 2+1 distal setae on apex. Maxilliped 2 and 3 (Figs 41 and 42): unchanged. Pereiopod 1 (Fig. 43): endopod developed, 4-segmented, with setal formula 0-02-2 setae; exopod with 2-2-2 natatory setae. Pereiopod 2-4 (Figs 44-46): endopod undeveloped; exopod developed with 2-2-2 natatory setae. Pereiopod 5 (Fig. 47): unchanged. Abdomen (Fig.
4): unchanged. Telson (Fig. 48): narrower than previous stage with five pairs of marginal setae; endopod developed with 9+3 setae plumose marginal setae; exopod with 11 plumose setae and one simple seta on the dorsal margin.

\section{DISCUSSION}

While larvae for species of Alpheus have been described, except for $A$. heterochaelis where larval development was complete (Knowlton 1973), another 21 species - A. armillatus, $A$. brevicristatus De Haan, 1849, A. sudara Banner and Banner, 1996, A. dentipes Guerin, 1832, A. laevis Randall, 1839, A. normanni, A. japonicus Miers, 1879, A. digitalis De Haan, 1850, A. rapacida De Man, 1908, A. rapax Fabricius, 1798, A. strenuus Dana, 1852, A. ventrosus H. Milne-Edwards, 1837, A. edwardsii (Audouin, 1827), A. euphorsyne richardsoni Yaldwyne, 1971, A. heeia Banner \& Banner, 1975, A. lottini Guérin-Méneville, 1829, A. macrocheles, A. lobidens De Haan, 1850, and Alpheus albatrossaie Banner, 1853 - failed to develop in culture attempts and so descriptions of their larval stages are incomplete (YANG \& KIM 1996, 1998, 1999, 2002, 2006, YANG et al. 2003). Alpheus estuariensis was similar, in that all larvae survived for four stages, but then subsequently died (zoea IV). The intermoult interval was very short (daily) in A. estuariensis for each larval stage. 


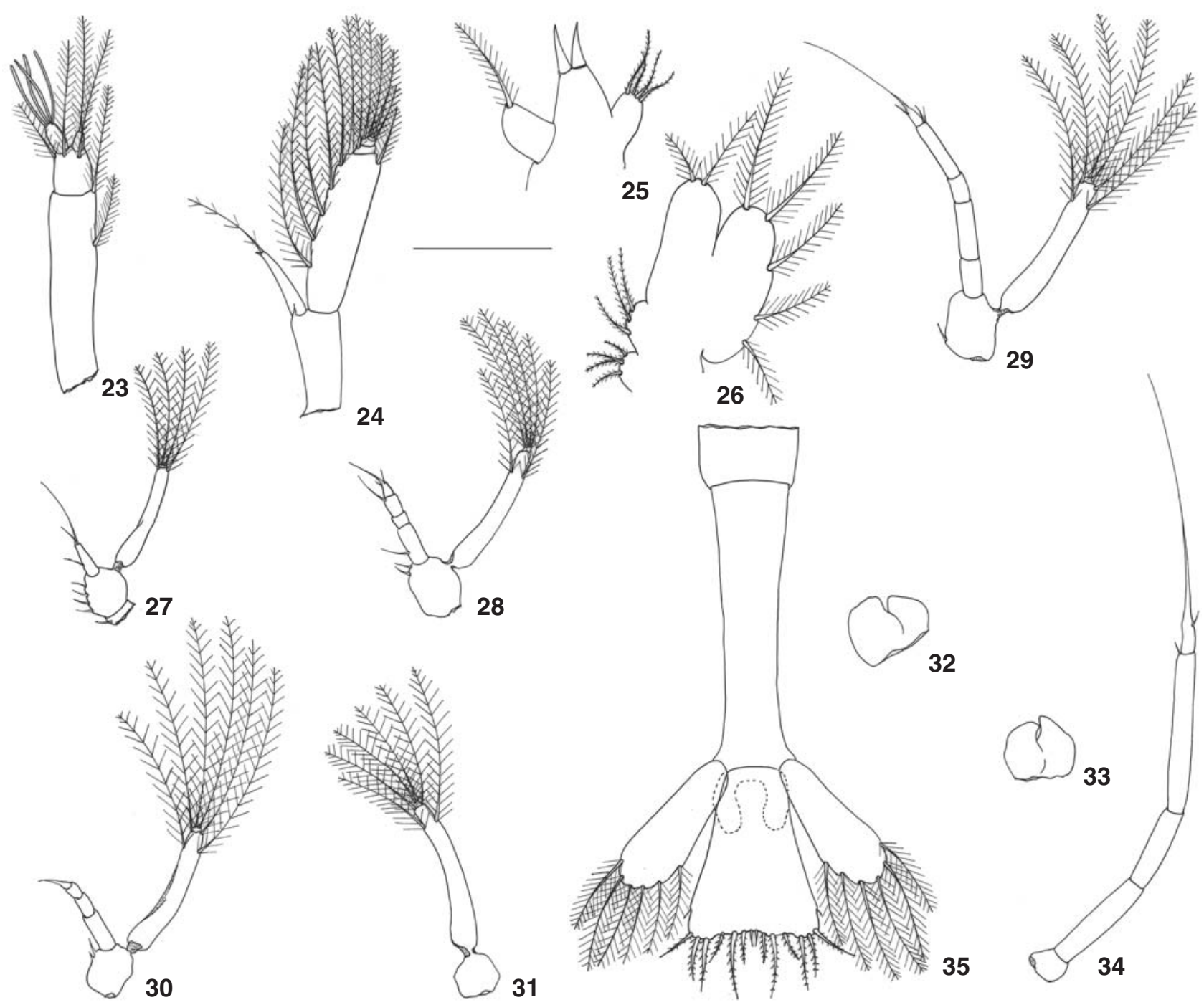

Figures 23-35. Alpheus estuariensis, zoea III appendages: (23) antennule; (24) antenna; (25) maxillule; (26) maxilla; (27) first maxilliped; (28) second maxilliped; (29) third maxilliped; (30) first pereiopod; (31) second pereiopod; (32) third pereiopod; (33) fourth pereiopod; (34) fifth pereiopod; (35) telson. Scale bar: 23-24, 27-31, 34-35 =0.3 mm, 25-26 $=0.75 \mathrm{~mm}, 32-33=0.15 \mathrm{~mm}$.

A morphological comparison shows that the first zoeal stage of $A$. estuariensis larvae is similar to that of other alpheids species (Tab. I). This similarity may contribute to the difficulty of specific identification. Nevertheless, differences do exist that should be useful for identification. Setation of the outer flagellum of the antennule is unique in bearing four aesthetascs, as compared to three in all other species.

The number of distal segments also vary, with $A$. estuariensis, A. japonicus and A. euphorsyne richardsoni having 4-segments while other species vary. The number of setae on the coxal endite is variable: A. estuariensis, A. euphorosyne richardsoni, $A$. heeia, A. digitalis, A. japonicus and A. brevicristatus all have three, while A. sudara, A. lobidens and A. heterochaelis vary. Also, A. estuariensis, A. brevicristatus, A. heterochaelis and A. heeia all have the same number of spines on the basal endite and all lack setae, while A. lobidens, A. japonicus, A. digitalis, A. euphorsyne richardsoni and $A$. sudara have one or two additional setae. The endopod of the second maxilliped is 4-segmented for all species except $A$. brevicristatus and $A$. japonicus, which are 3-segmented. Alpheus estuariensis has been confused with the very similar A. heterochaelis (CHRISTOFfersen 1984). However, as we show here, larvae have several differences that allow specific identification (Tab. I). The most distinct differences that separate these two species are: one seta on the maxillule coxal endite in A. heterochaelis 


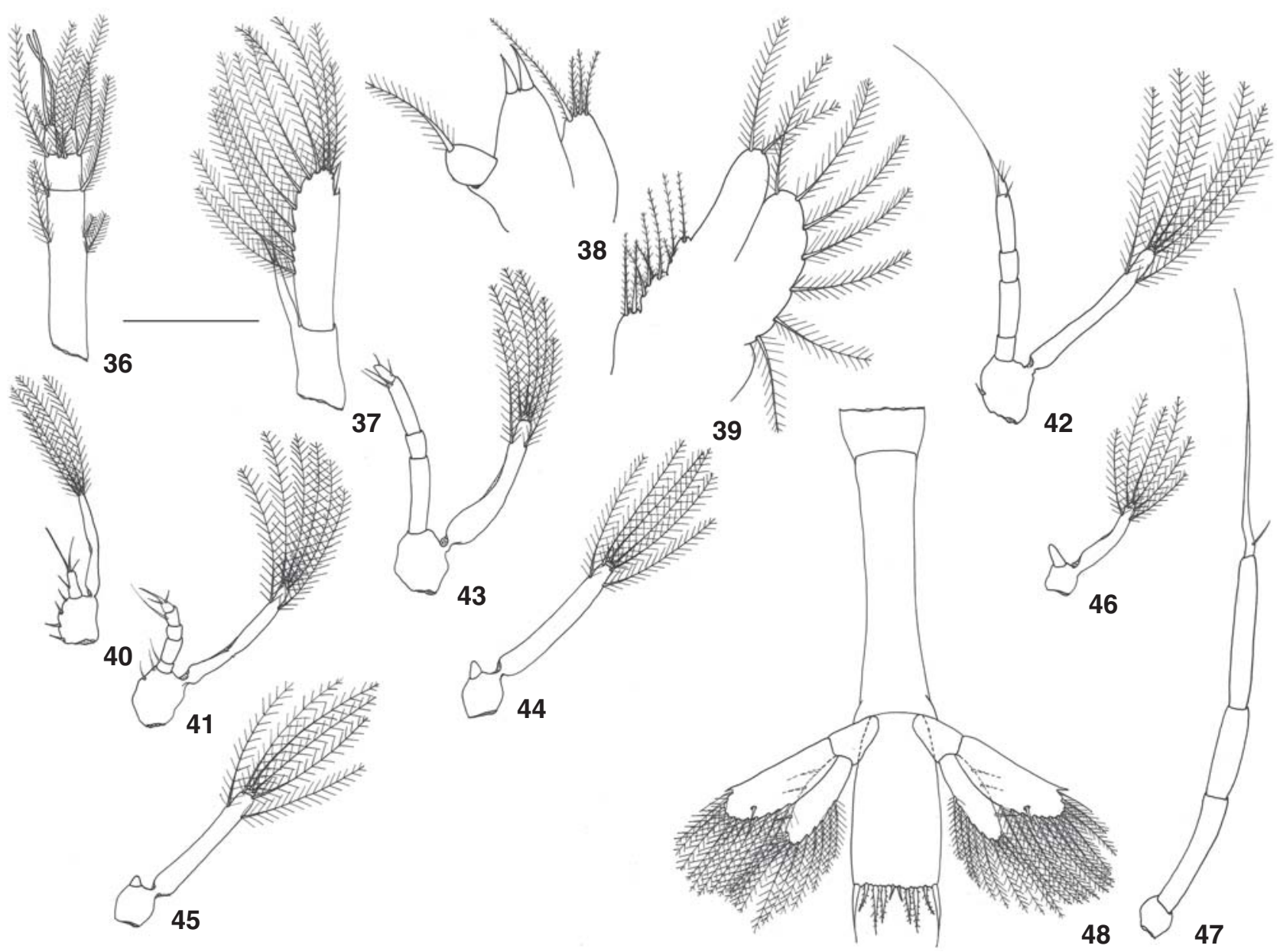

Figures 36-48. Alpheus estuariensis, zoea IV appendages: (36) antennule; (37) antenna; (38) maxillule; (39) maxilla; (40) first maxilliped; (41) second maxilliped; (42) third maxilliped; (43) first pereiopod; (44) second pereiopod; (45) third pereiopod; (46) fourth pereiopod; (47) fifth pereiopod; (48) telson. Scale bar: $36-37,40-48=0.3 \mathrm{~mm}, 37-38=0.075 \mathrm{~mm}$.

and three setae in A. estuariensis; 8-10 setae on the scaphognathite of the maxilla of $A$. heterochaelis and five setae in A. estuariensis.

\section{ACKNOWLEDGEMENTS}

Sincere thanks to Martin Christoffersen, Universidade Federal da Paraíba, and to Hoi Jeong Yang, Pusan National University. We are also grateful to Gustavo de Melo, (Museu de Zoologia, Universidade de São Paulo) for confirmation of the species identification.

\section{LITERATURE CITED}

Bartilotti, C.; R. Calado \& A. Santos. 2005. Correct diagnosis of early zoeal stages of Athanas nitescens (Leach, 1814) (Decapoda, Caridea, Alpheidae) using laboratory-raised larvae. Journal of Plankton Research 27 (11): 1189-1194.
Christoffersen, R.T. 1984. The Western Atlantic snapping shrimps related to Alpheus heterochaelis Say (Crustacea, Caridea), with the description of a new species. Papeis Avulsos de Zoologia 53 (19): 189-208.

Christoffersen, R.T. 1998. Malacostraca-Eucarida-CarideaCrangonoidea and Alpheidae, p. 353-372. In: P.S. Young (Ed.). Catalogue of Crustacea of Brazil. Rio de Janeiro, Museu Nacional.

KNowlton, R.E. 1973. Larval development of the snapping shrimp Alpheus heterochaelis Say, reared in the laboratory. Journal of Natural History 7: 273-306.

GuterRes, L.F.R.; G.A.S. Melo, \& P.M.C. GuterRes. 2005. Novos registros da ocorrência de Alpheus macrocheles (Crustacea, Caridea, Alpheidae) na costa do Brasil. Biociências 13 (2): 231-233.

Gross, P.S. \& KNowlton, R.E. 1999. Variation in larval size after eyestalk ablation in larvae of the snapping shrimp Alpheus

Revista Brasileira de Zoologia 25 (2): 199-205, June, 2008 


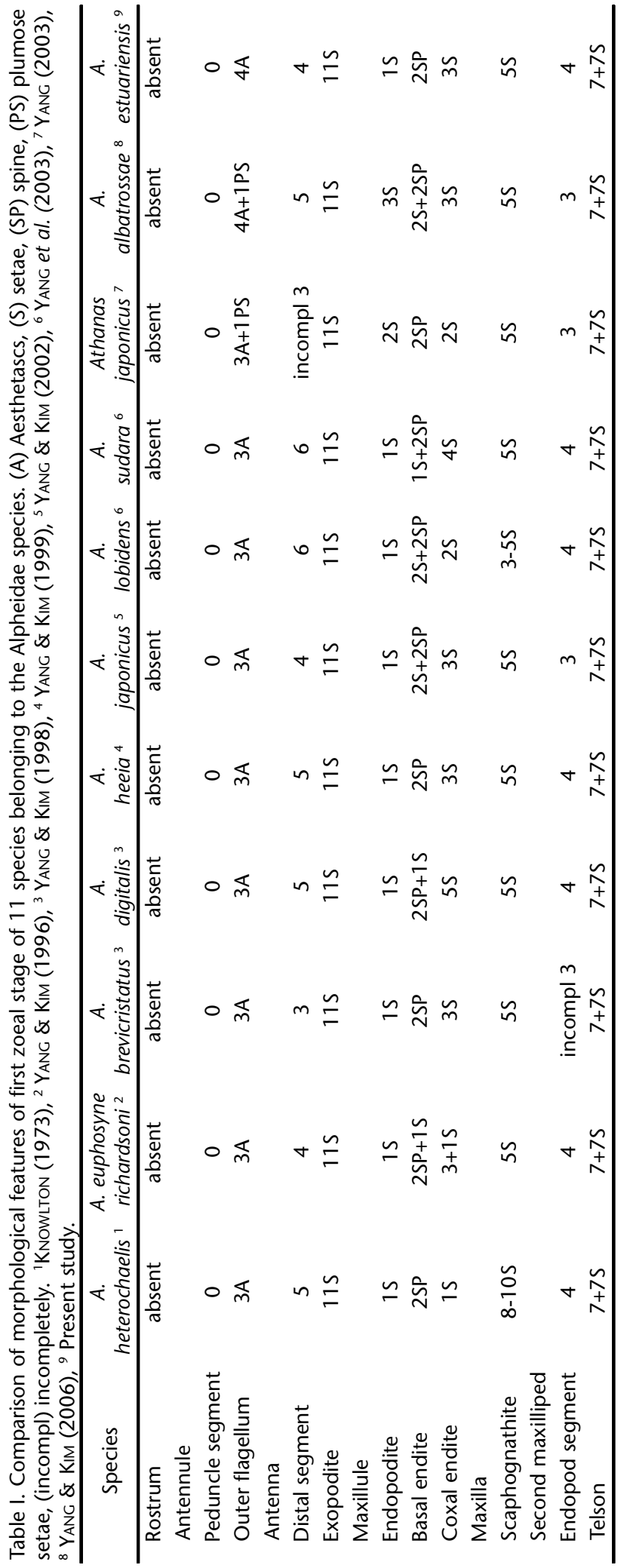

heterochaelis. Journal of Crustacean Biology 19 (1): 8-13. Lebour, M.V. 1932. The larval stages of the Plymouth Caridea. IV. The Alpheidae. Proceedings of the Zoological Society of London: 463-469.

Mossolin, E.C.; R.M. Shimizu \& L.S. Bueno. 2006. Population structure of Alpheus armillatus (Decapoda, Alpheidae) in São Sebastião and Ilhabela, southeastern Brazil. Journal of Crustacean Biology 26 (1): 48-54.

YANG, H.J. 2003. Early zoeas of Athanas japonicus Kubo, 1936 (Decapoda, Caridea, Alpheidae) reared in the Laboratory. Crustaceana 76 (4): 443-452.

YANG, H.J. \& C.H. KIM. 1996. Zoeal stages of Alpheus euphorosyne richardsoni Yaldwyne, 1971 (Decapoda: Macrura: Alpheidae) reared in the laboratory. Korean Journal of Zoology 39: 106-114.

YANG, H.J. \& C.H. KIM. 1998. Zoeal stages of Alpheus brevicristatus De Haan, 1849 (Decapoda, Macrura, Alpheidae) with a key to the first zoeal larvae of three Alpheus Species. Korean Journal of Biological Science 2: 187-193.

YANG, H.J. \& C.H. KIM. 1999. The early zoeal stages of Alpheus heeia Banner \& Banner, 1975 reared in the laboratory (Decapoda, Caridea, Alpheidae). Crustaceana 72 (1): 2536.

YANG, H.J. \& C.H. KIM. 2002. Early zoeas of two snapping shrimps Alpheus digitalis De Haan, 1850 and Alpheus japonicus Miers, 1879 (Decapoda, Caridea, Alpheidae) with notes on the larval characters of the Alpheidae. Korean Journal of Biological Science 6: 95-105.

YANG, H.J.; M.J. Kim \& C.H. Kim. 2003. Early Zoeas of Alpheus lobidens De Haan, 1850 and Alpheus sudara Banner and Banner, 1996 (Decapoda, Caridea, Alpheidae) Reared in the Laboratory. Korean Journal of Biological Sciences 7: 1524.

YANG, H.J. \& W. Kim. 2006. First Zoeas of Alpheus albatrossae (Decapoda, Caridea, Alpheidae) Hatched in the Laboratory. Korean Journal of Biological Sciences 22 (2): 189-194.

Submitted: 24.VIII.2007; Accepted: 02.VI.2008.

Editorial responsibility: Georgina Bond-Buckup 